\title{
Integrating Religiosity into Fraud Triangle Theory: Empirical Findings from Enforcement Officers
}

\author{
Jamaliah Said (Corresponding author) \\ Accounting Research Institute and Faculty of Accountancy \\ Universiti Teknologi MARA, Selangor, Malaysia \\ No Tel:- +603-5544 4891 E-mail: jamaliah533@salam.uitm.edu.my \\ Salsabila Asry \\ Faculty of Accountancy \\ Universiti Teknologi MARA, Selangor, Malaysia \\ No Tel:- +603-5544 4891 E-mail: salsabiilaasry@yahoo.com \\ Marhamah Rafidi \\ Accounting Research Institute and Faculty of Accountancy \\ Universiti Teknologi MARA, Selangor, Malaysia \\ No.Tel:-+0108966714 E-mail:marhamahrafidi89@gmail.com \\ Rawia Rida Obaid \\ Accounting Department \\ King Abdul Aziz University, Jeddah \\ No Tel:-+966500699574 E-mail: robead@kau.edu.my \\ Md. Mahmudul Alam \\ School of Economics, Finance \& Banking (SEFB), \\ College of Business (COB), Universiti Utara Malaysia (UUM), Sintok, \\ Kedah, Malaysia \\ Tel:-+6018-246 7050 E-mail: rony000@gmail.com
}

\begin{abstract}
Recently, employee-fraud has drawn extensive attention due to huge amount of losses of various organizations. This study developed a new model of fraud risk by integrating new elements into a fraud triangle theory. This study simultaneously analyzed religiosity and the three elements of fraud risk factors of employee fraud committed by low and mid-level public officials. The data collected from 120 enforcement officers indicated that religiosity is negatively related to employee fraud. By contrast, all the three elements of fraud triangle theory, namely, pressure, opportunity, and rationalization, are positively related to employee fraud. These results imply that strong religiosity is crucial to mitigate employee fraud. To minimize employee
\end{abstract}

fraud, the opportunity to commit such fraud should be reduced through strong internal control, reduction of negative rationalization, and employee financial pressure. This study contributes to the literature by introducing a new model on employee-fraud occurrence that is not extensively discussed, particularly in the context of local authority in developing countries.

Keywords: Local authority, Religiosity, Fraud Triangle, Employees Fraud

\section{Introduction}

Islam as a religion (or deen in Arabic) is a code that governs Muslim life, as well as a way of life that fuses the material and spiritual components. The word "Islam" means peace and obedience 
(Belfast Islamic Centre, 2016), thus, adhering to Islam requires Muslims to avoid any misconduct and acknowledge the reason why they exist in this world (Abdul Rahman, 2009). A Muslim should behave based on the guidelines set by Allah (SWT) in the Quran, as well as the teachings of the Prophet Muhammad (PBUH). This idea is consistent with the Quran verses, in which Allah (SWT) says that "We shall set up justice scales for the Day of Judgment, not a soul will be dealt unjustly in the least. And if there be (no more than) the weight of mustard seed, We will bring it (to account); and enough are We to take account" (Al-Qur'an Chapter 21 , verse 47).

We are impressed with the manner by which deen can control human behavior and conduct if people truly adhere to God's commands and rules. However, man occasionally forgets and loses faith because of many factors, such as poverty and wealth, thereby leading them to do the forbidden. At present, the world has witnessed numerous crimes and unethical behaviors vigorously taking place; these acts and behaviors are rooted in the non-adherence to the deen code of conduct. Fraud is one of the most evident and rampant crimes that is currently happening all over the world (Sharma, 2014).

The term "fraud" commonly refers to such activities as theft, corruption, scheme, misappropriation, money laundering, and extortion, among others (CIMA, 2008). Ruin (2009) explained that fraud is an act committed by a party or individual (e.g., avoiding obligation or causing financial or non-financial loss to another party) who uses deception with the intention of obtaining benefits. The Global Fraud Survey conducted by the Association of Certified Fraud Examiner (ACFE, 2014) revealed that fraud cases constitute $36.2 \%$ of the total number of government and public administration fraud cases.

Given the number of fraud cases and their respective losses to the Malaysian economy, fraud should be given serious attention. In 2003, the Commercial Crimes Investigation Department (CCID) investigated 11,714 cases of white-collar crime that involved approximately RM579 million. In 2004, the number of cases decreased to 9,899 , but the losses increased to RM836 million (Lim, 2005). The losses also increased slightly to RM846 million in 2008 and the number of significant cases increased to 17,311 (Bernama, 2009). In 2012, white-collar criminal activities included criminal breach of trust and embezzlement. Other white-collar crimes increased to 18,386 cases and incurred RM1.62 billion losses which increased to RM1.775 billion in 2013 (Mui, 2014). These figures indicate the severity of the fraud issue in recent years.

Several studies highlighted the reasons that prompt people to commit fraud, all of which are associated with the elements in the fraud triangle. Liew et al. (2011) ranked the motivations behind white-collar crimes in Malaysia, the first of which is the belief that competitors are paying bribes to win contracts. This ranking could be associated with the justification element in the fraud triangle. In addition, Liew et al. (2011) classified the reasons of fraud occurrence in terms of group motivation, where the highest rank is opportunistic causes, such as poor internal control, poor ethical practices, and lack of management control by directors.

However, Wolfe and Hermason (2004) argued that the model alone is inadequate to deter, prevent, investigate, and detect fraud. Unfortunately, Bressler and Bressler (2007) agreed that not every person who possessed motivation/pressure, opportunity, and rationalization may commit fraud due to capability. Albrecht, William, and Wernz (1995) opined that capability is particularly significant for large-scale and long-term fraud, whereas employee-fraud is often "street-level," smallscale, and short-term fraud. By contrast, Sens as cited in Beckley (2002) stated that capability is an opportunity that employs the concept of freedom as a "real opportunity." Therefore, 
integrating religiosity into the fraud triangle will provide a new and effective model.

Several studies focused on the other potential factors that may hinder fraud. A group of scholars proposed religiosity as one of the most prevailing factors that mitigate fraud (Akir \& Malie, 2012; Ima and Westi, 2011; Azizan \& Razlina, 2015; Sham \& Yusof, 2015). Hence, the present study attempts to integrate religiosity into fraud triangle theory to investigate the factors behind employee fraud among local enforcement authorities. In Kelantan, one of the capital cities, following the introduction of the mas'uliyyah and amanah concepts among public administrators by the Islamic Religious and Affairs Department of Kelantan in 2014. The concept of mas'uliyyah (accountability) and amanah (honesty) are two important pillars that ensure the integrity of civil servants and keep them clean from fraud (Musa, 2014). This concept is similar to that proposed in previous studies on religiosity (e.g., Akir and Malie, 2012; Baskoro, 2014; Mittroff and Denton, 1999; Said et al., 2015).

\section{Literature Review}

\section{Religiosity and Employee Fraud}

Religiosity from the Islamic viewpoint is defined as the awareness or consciousness of God, the desire to attain balance between worldly needs, and adherence to God's commands (Sham and Yusof, 2015). Therefore, religion aims to control human behavior in building fidelity and acquiescence (Ashiq, 2004). For Muslims, Islam as a religion is a framework or pillar that improves the behavior of believers (Jamal, 2003). Several studies have established the significance of religion in controlling human conduct. Akir and Malie (2012) determined that religious orientation is positively correlated with the job conduct of employees. That is, employees who are affiliated to a religion are considerably observant of company rules and regulations.

Pupung and Ima (2015) explained that fraud in the workplace will be easily prevented if religiosity exists. Weaver and Agle (2000), Ima and Westi, (2011), and Ima (2014) concluded that understanding religion can influence an individual's attitude and behavior. The Quran emphasizes on honesty. For example, surah al-Ahzab in verse 72 , surah al-Anfal in verse 27, and surah al-Mu'minun in verse 8 indicate the importance of honesty in Islam and the prohibition of unethical and fraudulent acts. This finding is consistent with that of Azizan and Razlina (2015), who determined that religious workers have positive job attitudes despite facing incivility in their workplace. This mindset means that they should improve their understanding and devotion to Islamic practices in the workplace to resist unethical practices. Said et al. (2015) determined that religiosity is negatively associated with the occurrence of asset misappropriation among Royal Malaysian Police officers. Therefore, the following hypothesis is proposed:

\section{H1: A negative relationship exists between religiosity and employee fraud.}

\section{Pressure and Employee Fraud}

Cressey (1953) noted that when a fraud perpetrator does not disclose a financial problem, such inaction motivates him to commit wrongdoings. This non-disclosure of a financial problem was later expanded by Kranacher et al. (2011), who also included other non-financial pressures. Findings from previous research showed the influence of pressures on fraud occurrence (Albrecht et al., 2010; Rezaee, 2005; Widianingsih, 2013). These studies suggest that if pressures exist, a person or organization tends to commit fraud whether such fraud involves monetary or non-monetary aspect. In this context, Dellaportas (2013) argued that an individual tends to be involved in fraudulent behavior to solve or reduce their financial or personal pressures.

Hernandez (2007) determined that pressure on a worker and the probability to commit fraud 
in the workplace are positively related. This result indicates that the drive to perform also increases the tendency to behave fraudulently that provides a benefit in salary increment. The pressure to obtain bonuses and high wages also has a positive influence on the practice of fraud among employees (Hernandez, 2007).

The survey conducted by ACFE in 2012 indicated that among the most prevalent signs of fraud are as follows: offenders often live beyond their means, spend extravagantly, and face financial distress. These findings are consistent with the subsequent global fraud survey undertaken by ACFE in 2014 titled $A$ Report to The Nations on Occupational Fraud and Abuse, which discovered that a total of $44 \%$ of fraud offenders were maintaining beyondtheir-budget lifestyles and another 33\% were struggling with financial difficulties. In 2012, KPMG Australia and New Zealand reported that $36 \%$ of the respondents indicated that the major factor motivating people to commit fraud was personal financial pressure, while 31\% indicated greed and other types of pressures. Therefore, the following hypothesis is proposed:

\section{H2: A positive relationship exists between pressures and employee fraud}

\section{Opportunity and Employee Fraud}

Previous studies report that the perpetration of fraudulent behavior is also associated with opportunity (e.g., Coleman, 1987; Lister, 2007; Wells, 2001). Albrecht et al. (2010) believed that this element has a significant contribution to fraud occurrence, particularly when combined with extreme pressure. Opportunity refers to the weak internal control that exists in an organizational environment (Kassem \& Higson, 2012; Mui \& Mailley, 2015; Wolfe and Hermanson, 2004). Insufficient supervision and lack of division of duties also contribute to fraud (Dellaportas, 2013). The inmates interviewed by Dellaportas have admitted that these loopholes in the workplace are the reason for their fraudulent acts, such as embezzlement and loan manipulation. The presence of opportunity enables employees to believe that their probability of getting caught is low, thereby enticing them to commit fraud (Cressey, 1953; Albrecht, Albrecht, Albrecht and Zimbelman 2008). These findings are consistent with the survey by PWC in 2011, which determined that such opportunities as inadequate division of duties caused by the reduction in the number of employees caused fraud.

The KPMG Malaysian Fraud, Bribery, and Corruption (2013) Survey reported the following most influential opportunities in the workplace that cause fraud and unethical conduct: loopholes in internal control, inadequate competency of the internal audit team to detect fraud, insufficient training to build awareness on fraud, nature of the particular industry that is prone to fraud, failure to convey the organization's code of ethics and values (81\%), poor example provided by upper-level staff (43\%), and poor ethical culture within the organization (38\%). Therefore, the following hypothesis is proposed:

\section{H3: A positive relationship exists between opportunity and employee fraud.}

\section{Rationalization and Employees Fraud}

Rationalization is recognized as the leading contributor to fraud. For example, in terms of financial misstatements, rationalization was established as the leading factor that causes people to be tolerant of employee fraud (Kula et al., 2011). Employee fraud was determined to be acceptable in companies, thereby indicating the rationalization of employees committing crimes. In terms of asset misappropriation, Mohamed et al. (2014) determined that nearly all respondents agreed that rationalization was a factor that leads to fraud, particularly with the sense that "others are doing it as well." Cleff et al. (2013) stated that adapting a sense of right and wrong to fit criminal behavior by a fraudster can also be categorized as rationalization.

Therefore, rationalization is a complex reason for people opting to do fraudulent activities 
because it involves arguments that may be considerably judgmental. Cleff et al. (2013) explained that a fraudster will attempt to adapt his sense of right and wrong to fit the criminal behavior. Thereafter, this approach will seem to rationalize the criminal behavior and the fraudster can continue with the act without guilt.

Mohamed et al. (2014) studied asset misappropriation and determined that nearly all respondents agreed that "others are doing it as well" is a common rationalization used in doing this type of fraud. Hence, rationalization influences the occurrence of fraud because people tend to rationalize their fraudulent acts. That is, the rationalization factor is positively associated with the occurrence of employee fraud among local enforcement officers. Therefore, the following hypothesis is proposed:

H4: A positive relationship exists between rationalization and employee fraud

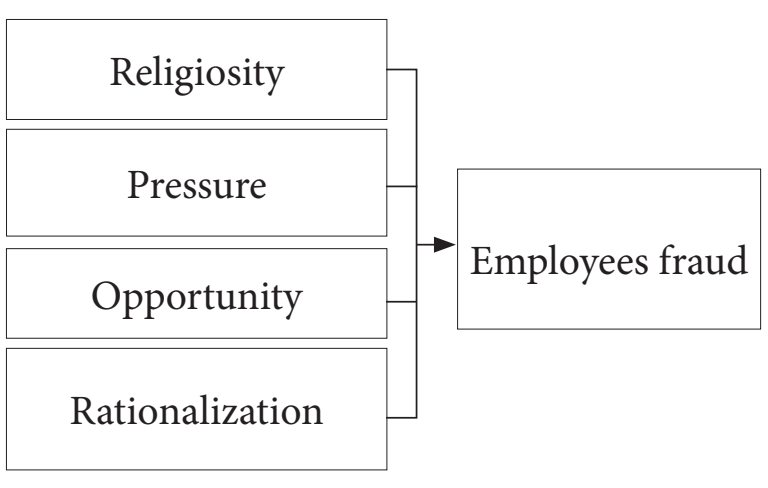

Figure 1: Conceptual framework

\section{Methodology}

\section{Data Collection}

A total of 120 questionnaires were distributed to the enforcement officers involved in the daily monitoring and patrolling of their respective areas during a monthly meeting held by the largest local authority in Kelantan. The distribution was conducted with the permission of the head of the Enforcement Division. All the respondents were given 30 minutes to answer the questionnaire and submit the completed forms in the box provided. To ensure confidentiality, the personal details of the respondents, such as name or staff number, were not asked. A total of 103 answered questionnaires were collected during the event. The enforcement officers were selected as respondents because they have a high potential to be involved with employee fraud. For example, the responsibility of collecting fines and compounds from the local citizens who violate the rules set by the municipal council may tempt these officers because the public may offer gifts and cash to avoid paying the fines and compounds.

\section{Variable Measurements}

\section{Demographic}

The first part of the questionnaires is on the respondents' demographic information. The six questions that were asked were about the respondents' gender, age, position, monthly salary, years of service, and level of education.

\section{Employees Fraud}

A total of 11 items to measure employee fraud were adopted (with a few modifications) from Nia (2016); Said et al. (2015); Gonzales, Schofield, and Schmitt (2005); Klockars, Ivkovich, Harver, and Haberfeld (2000); and Weisburd et al. (2000). The respondents were asked to rate their agreement/disagreement on whether they have experienced accepting gifts, money, benefits in kind, discount, or free food from any restaurant owner/community.

\section{Religiosity}

El-Menouar (2014) suggested 11 indicators of a Muslim's religiosity, including belief, ritual, devotion, experience, knowledge, devotion, and consequences. Therefore, questions were asked to assess a Muslim's level of religiosity based on these indicators. The questions were adopted (with a few modifications) from the 
Comprehensive Measure of Islamic Religiosity used in the previous studies of Abdullah and AlKhalifah (1994), Shukor and Jamal and Shukor (2013), and Siguaw and Simpson (1997). These studies established the measurement model to measure the religiosity of an individual, including the extent of the respondents' religious activities in terms of performing compulsory daily prayers, fasting, sadaqah, reciting the holy Al Quran, and following the sunnah of the Prophet.

Pressure

A total of $10 \mathrm{n}$ questions were asked regarding the financial and non-financial pressures faced by the respondents in fulfilling their daily duties. The questions were adopted (with a few modifications) from Said et al. (2015), Rezae and Davani (2013), Dellaportas (2013), Kassem and Higson (2012), and Wolfe and Hermanson (2004). Thereafter, the respondents were requested to rate their agreement/disagreement on the financial and work pressures they had experienced.

\section{Opportunity}

Six questions on opportunity were adopted and modified from Nia (2016), Said et al. (2015), Dellaportas (2013), Kassem and Higson, (2012), and Wolfe and Hermanson (2004) to match the environment of the local authority and duties of the enforcement officers. The items included internal control activities, such as the existence of supervision, monitoring, and review on work responsibility.

\section{Rationalization}

Six questions on rationalization were adopted (with a few modifications) from Nia (2016), Said et al. (2015), Wolfe and Hermanson (2004), Dellaportas (2013), Kassem and Higson, (2012), Tugas (2012), and Paul et al. (2008) to cater to the working environment of the local enforcement officers.

\section{Results and discussion}

\section{Descriptive Analysis}

A total of 103 out of the 120 distributed questionnaires were received from the Kota Bharu Municipal Council enforcement officers. The first part consists of the demographic information that comprises questions on gender, age, position in the unit, monthly salary, years of service, and level of education. From the survey, 71 respondents $(68.93 \%)$ are male and the other 32 respondents $(31.07 \%)$ are female. In terms of age, 55 respondents are under 30 years old $(53.40 \%)$, followed by those aged $30-40$ years $(17.48 \%), 41-50$ years $(13.59 \%)$, and 51 years and above $(15.53 \%)$. Among the 103 respondents, $18(17.48 \%)$ are enforcers, 84 are assistant enforcers $(81.55 \%)$, and 1 is a law enforcer $(0.97 \%)$. The average monthly earnings of the majority of the respondents (i.e., 71 respondents, 68.93\%) ranged from RM1000 to RM2000, followed by those earning from RM2001 to RM3000 (i.e., 30 respondents, $29.13 \%$ ), and those earning from RM3001 to RM4001 (i.e., 2 respondents, 1.94\%).

In terms of service period, 41 (39.81\%) respondents have served MPKB for under 1 year, while 33 (32.04\%) have served MPKB for over 5 years, followed by $17(16.50 \%)$ respondents with 1 to 3 years of service experience, and $12(11.65 \%)$ respondents have worked for 4 to 5 years in MPKB. In terms of education level, the respondents are mostly lower level/ certificate qualified, with $77(74.76 \%)$ out of the 103 respondents, followed by 13 respondents $(12.62 \%)$ with diplomas, and 12 (11.65\%) degree holders.

\section{Diagnostic analysis}

Table 1: Exploratory Data Analysis
\begin{tabular}{|l|l|l|l|l|}
\hline Variables & Mean & Skewness & Kurtosis & $\begin{array}{l}\text { Cronbach's } \\
\text { Alpha }\end{array}$ \\
\hline $\begin{array}{l}\text { Employees } \\
\text { Fraud }\end{array}$ & 0.9429 & 1.370 & 1.954 & 0.935 \\
\hline
\end{tabular}




\begin{tabular}{|l|l|l|l|l|}
\hline Religiosity & 3.7243 & -0.066 & -0.742 & 0.833 \\
\hline Pressure & 3.2981 & 1.136 & 1.525 & 0.845 \\
\hline Opportunity & 3.6033 & -0.469 & 1.487 & 0.795 \\
\hline Rationalization & 2.8904 & -0.073 & -0.073 & 0.835 \\
\hline
\end{tabular}

Exploratory data analysis (EDA) was performed to ensure the normal distribution from a large data set. Table 1 shows that the range of skewness values for all the variables are from -0.066 to 1.370 , while the range of kurtosis is from -0.073 to 1.954 . Therefore, all data were considered normal.

Nunally (1978) and Pallant (2007) stated that any value of 0.70 and above would be acceptable for a good measure of internal consistency. The Cronbach's Alpha values for employee fraud, religiosity, pressure, opportunity, and rationalization were $0.935,0.833,0.845,0.795$, and 0.835 , respectively, thereby indicating good internal consistency of data.

The Kaiser-Meyer-Olkin coefficients were $0.899,0.726,0.804,0.736$, and 0.731 for employee fraud occurrence, religiosity, pressure, opportunity, and rationalization, respectively, thereby indicating that the data could be used to proceed with the exploratory factor analysis (Hair et al., 2010). The principal component analysis (PCA) of employee fraud occurrence has an eigenvalue of 7.211 (i.e., above 1 ), thereby signaling $65.556 \%$ variance of explanation for converting into one factor. PCAs of religiosity, pressure, opportunity, and rationalization have eigenvalues (and variance of explanations) of 4.388 (43.882\%), 3.94 (49.246\%), $2.805(56.1 \%)$, and 3.382 $(56.373 \%)$, respectively.

Table 2 shows the summary of the results where the bivariate analysis is applied to test the correlation between one variable to another. Table 2 also shows that the employee fraud variable indicates a small correlation with both religiosity and pressure at the 0.05 significance level when their $\mathbf{r}$-values are -0.238 and 0.243 , respectively. Employee fraud has a medium correlation with rationalization because the r-value is 0.445 at the 0.01 significance level. Meanwhile, employee fraud has a large correlation with opportunity, with an $\mathbf{r}$-value of 0.511 at the 0.01 significance level. Overall, the results from the correlation analysis indicate a mixed correlation between the variables, where employee fraud is positively correlated with each element in the fraud triangle (i.e., pressure, opportunity, and rationalization) and negatively correlated with religiosity.

Table 2: Pearson's Correlations

\begin{tabular}{llllll}
\hline & Employee Fraud & Religiosity & Pressure & Opportunity & Rationalization \\
\cline { 2 - 6 } Employees fraud & 1.000 & $-0.238^{*}$ & 0.243 & $0.511^{*}$ & $0.445^{* *}$ \\
Religiosity & 1.000 & -0.169 & 0.043 & 0.107 \\
Pressure & & 1.000 & -0.053 & $0.259^{* *}$ \\
Opportunity & & & 1.000 & 0.017 \\
Rationalization & & & & 1.000 \\
\hline
\end{tabular}

** Correlation is significant at the 0.01 level (two-tailed). * Correlation is significant at the 0.05 level (two-tailed).

Table 2: ANOVA

\begin{tabular}{|l|l|l|l|l|l|l|}
\hline \multicolumn{2}{|c|}{ Model } & Sum of Squares & Df & Mean Square & F & Sig. \\
\hline \multirow{2}{*}{} & Regression & 23.078 & 4 & 5.770 & 24.514 \\
\cline { 2 - 7 } & Residual & 23.065 & 98 & 0.235 & \\
\cline { 2 - 7 } & Total & 46.143 & 102 & & & \\
\hline
\end{tabular}

a. Dependent Variable: Employees Fraud

b. Predictors: (Constant), Rationalization, Opportunity, Religiosity, and Pressure 
Table 3 shows the results from the regression analysis, which indicates that religiosity has a significant negative relationship with employee fraud. Meanwhile, pressure, opportunity, and rationalization have significant positive relationships with employee fraud. The adjusted $\mathrm{R}^{2}$ shown in Table 3 is 0.707 , thereby indicating that $70.7 \%$ of the variation within employee fraud can be described by religiosity, pressure, opportunity, and rationalization. In addition, the Durbin-Watson value is approximates 2 (i.e., 1.538), thereby indicating the non-problematic correlations of the residuals, particularly the multicollinearity problem.

Table 3: Multiple Regressions

\begin{tabular}{lllll}
\hline Variables & $\begin{array}{l}\text { Standardized } \\
\text { Coefficient }\end{array}$ & $\begin{array}{l}\text { Std. } \\
\text { Error }\end{array}$ & t-stat & p-value \\
\hline Constant & & 0.882 & -0.570 & 0.570 \\
Religiosity & -0.151 & 0.097 & -2.076 & 0.040 \\
Pressure & 0.146 & 0.215 & 1.947 & 0.054 \\
Opportunity & 0.506 & 0.068 & 7.064 & 0.000 \\
Rationalization & 0.382 & 0.052 & 5.154 & 0.000 \\
\hline R & & & $0.707^{\mathrm{a}}$ & \\
$\mathrm{R}^{2}$ (Adjusted $\left.\mathrm{R}^{2}\right)$ & & & 0.480 & \\
F-statistic & & & & \\
(p-value) & & & & \\
Durbin-Watson & & & & \\
statistic & & & & \\
Significance at $\mathrm{p}$ & & & & \\
$<0.05$ & & & & \\
\hline
\end{tabular}

Table 3 presents a significant negative relationship between religiosity and employee fraud, with the coefficient for religiosity at $-0.151, \mathrm{t}=-2.076, \mathrm{p}=0.040$. Hence, $\mathrm{H} 1$ is supported. This finding is consistent with those of several previous studies on the influence of religiosity on the behavior, morale, integrity, and ethics of employees in the workplace (Akir \& Malie, 2012; Weaver \& Agle, 2002). The negative relationship between religiosity and employee fraud indicates that a high level of religiosity can reduce the occurrence of employee fraud. This finding is also consistent with the current study of Pupung and Ima (2015) on Indonesian auditors. They concluded that fraud in the workplace will be easily prevented if religiosity exists. This finding is closely associated with the emphasis on honesty and prohibition of unethical fraudulent acts in our religion (Quran, 33:72; 8:27 and 23:8) because Muslims should constantly be aware that Allah (SWT) knows all our deeds.

The second objective of this study is to investigate the relationship between pressure and the occurrence of employee fraud. A high level of pressure promotes the occurrence of employee fraud. Table 3 shows a significant positive relationship between pressure and employee fraud, with the coefficient value at $0.146, \mathrm{t}=1.947, \mathrm{p}=0.054$. Hence, $\mathrm{H} 2$ is supported. The result agrees with various studies conducted on the effects of pressures on the perpetration of fraudulent behavior, such as asset misappropriation, financial statement fraud, and briberies among employees in the private and public sectors (Rezaee, 2005; Hernandez, 2007; Dellaportas, 2013; Mohamed et al., 2014).

The third objective of this research is to analyze the relationship between opportunity and the occurrence of employee fraud. Table 3 reveals a significant positive relationship between opportunity and employee fraud, with the coefficient value of $0.506, t=7.064, p=0.000$. Therefore, $\mathrm{H} 3$ is supported. This result validates the survey conducted by PWC in 2011, which revealed that opportunities in the workplace, such as inadequate duty segregation caused by the reduction in the number of employees, is a cause of fraud (Dellaportas, 2013).

The fourth objective of this study is to analyze the relationship between rationalization and the occurrence of employee fraud. H4 proposed that a positive relationship exists between rationalization and employee fraud, with the assumption that the occurrence of such fraud will increase if the attempt to justify it increases. Table 3 presents a significant positive relationship between rationalization and employee fraud, with the coefficient value at $0.382, \mathrm{t}=5.154, \mathrm{p}=0.000$. Thus, $\mathrm{H} 4$ is also supported. This result proves the ACFE (2014) 
report on global occupational fraud survey that people will rationalize a crime before committing it (ACFE, 2014). It also verifies various studies that determined rationalization to be one of the motives behind fraud perpetration (Cleff et al., 2013; Kula et al., 2011; Mohamed et al., 2014). This result also supports Said et al. (2015), who determined a positive relationship between opportunity with the incidents of fraud among Royal Malaysian Police Officers. In addition, the result corroborates the survey conducted by KPMG (2011) in Singapore, where rationalization was determined to be a predominant reason among fraud first-timers who view their actions as non-criminal.

\section{Conclusion}

This study developed a new model of factors that may influence employee fraud by integrating the elements of religiosity into fraud triangle theory. This study was motivated by the lack of empirical research on employees and insufficient research on fraud among enforcement officers, who are considered the most susceptible group of employees to fraud due to the nature of their work. In addition, previous studies have failed to integrate new elements in the analysis. Accordingly, simultaneously assessing religiosity and the risk elements of fraud in a single study is crucial to highlight the significance of each element to employee fraud. The results of this study proved that religiosity has a positive influence on employee fraud, whereas the elements in the fraud triangle (i.e., pressure, opportunity, and rationalization) have positive effects on employee fraud among enforcement officers in a large local authority.

Evidence from the current study also indicated that certain situations may create an opportunity for enforcement officers to commit fraud. Therefore, based on the element of opportunity, new rules and procedures must be developed to decrease the number of employees attempting fraudulent advantages. The findings of the present research proved that the element of pressure has a significant relationship with employee fraud. Thus, local authorities should be aware of the factors that may cause pressure for their enforcement officers. The top local authorities can use these findings as guidelines to monitor their work environment and evaluate the job value of employees. Moreover, the results have shown that rationalization had a positive relationship with employee fraud; thus, local authorities should acknowledge that most people need to reconcile their behavior with the commonly accepted notions of decency and trust. Moreover, top management should monitor the behaviors of their employment officers, as well as identify their personalities and attitude, to reduce employee fraud.

\section{References}

Abdul Rahman, A.R. (2009). An Introduction to Islamic Accounting Theory and Practice. Cert Publications. ISBN : 978-967-0175-01-1

Abdullah H.M. \& Al-Khalifah (1994). Religiosity in Islam as a Protective Mechanism Against Criminal Temptation, The American Journal of Islamic Social Sciences, 11(1), 1-12.

Akir, O. \& Mallie, S. (2012). Integrity Dimensions and Religious Orientation in Aspect of Employees Job Conduct: An Exploratory Model Building. Procedia Social and Behavioral Sciences, 62(1), 167-174

Albrecht, C., Turnbull, C., Zhang, Y. \& Skousen, C.J. (2010). The relationship between South Korean Chaebols and fraud. Management Research Review 33(3), 257 - 268.

Albrecht, W. S. (1991). Fraud in Government Entities: The Perpetrators and the Types Of Fraud. Government Finance Review 7(6), 2730.

Albrecht, W., S., Albrecht, C.,O.,Albrecht, C.,C., \& Zimbleman, M.,F., (2008). Fraud examination, Cengage Learning, South-Western, Mason, USA. 
Ashiq, A. S. (2004). Self-Religiosity, Father's Attitude And Religious Education In The Moral Behaviour Of Adolescents, Psychology Developing Societies 16(2), 187-207.

Association of Certified Examiner. ACFE. (2014), Report to the Nations on Occupational Fraud and Abuse, 2014 Global Fraud Study, ICFE Publisher, Retrieved from https://www. acfe.com/rttn/docs/2014-report-to-nations.pdf

Association of Certified Fraud Examiners, ACFE (2012). Report to the Nations on Occupational Fraud and Abuse. ACFE Publisher, USA, Retrieved from https://www. acfe.com/uploadedFiles/ACFE_Website/ Content/rttn/2012-report-to-nations.pdf

Azizan, H., M. \& Razlina, H.J., (2015). Relationship between Workplace Incivility, Job Attitudes and Muslim Religiosity Personality among Trade Union Members. Global Journal Al-Thaqafah 5(2), 43-51.

Baskoro, Radita D., (2014) Spirituality on Employees' attitude. Human Capital Journal, no. 31, Year III, January-February.

Beckley, H. (2002). Capability as opportunity. How Amartya Sens revises Equal opportunity. Journal of Religion Ethics, 30(1), 107-135.

Belfast Islamic Centre, The Meaning of Islam, Muslim Youth of Northern Ireland. Retrieved from: http://belfastislamiccentre.org.uk/

Bernama (2009). White-collar crimes accounted for RM788 mil losses last year (19 June). Retrieve from http://www.insuranceonline. my/2009/06/white-collar-crimes-accountedfor-rm788 millosseslast-year-igp/

Bressler, M. S., \& Bressler, L. A. (2007). Amodel for prevention and detection of criminal activity impacting small business. The Entrepreneurial Executive, 12(1), 23-36.
CIMA. (2008). Chartered Institute of Management Accountants; Fraud risk management; A guide to good practice. Available at www.cimaglobal.com

Cleff, T., Naderer, G. \& Volkert, J., (2013). Motives Behind White $\square$ Collar Crime: Results Of A Quantitative And Qualitative Study In Germany. Society and Business Review 8(2), 15-145.

Coleman, J. W. (1987). Toward An Integrated Theory of White-Collar Crime. American Journal of Sociology, 93(2), 406-439.

Cressey, D. R. (1953). Other People's Money: A Study in the Social Psychology of Embezzlement. The Free Press Publisher.

Dellaportas, S. (2013). Conversations with inmate accountants: Motivation, opportunity and the fraud triangle. Accounting Forum, 37(1), 29-39.

El-Menouar, Y., (2012). The Five Dimensions of Muslim Religiosity. Results of an Empirical Study, Methods, data, analyses, 8(1), 53-78.

Gonzales, A. R., Schofield, R. B., \& Schmitt, G. R. (2005). Sexual assault on campus: What colleges and universities are doing about it. Retrieved from National Criminal Justice Reference Service website: http://www.ncjrs. gov/pdffiles1/nij/205521.pdf

Hair, J.F., Black, W.C., Babin, J.B., Anderson, R.E. (2010), Multivariate data analysis (7th ed.). USA: Prentice Hall, Inc.

Harrison, E. 2007. Corruption. Development in Practice, 17(4-5), 672-678.

Hassan, B.B. \& Muhamad, Y. R., (2009). Religiosity and work stress coping behavior of Muslim employees. Education, Business and Society: Contemporary Middle Eastern, 2(2), 123-137. 
Hernandez, J. R., \& Groot, T. (2007). Corporate fraud: Preventive controls which lower fraud risk. Research Memorandum ARCA, Research Center in Accounting, Amsterdam University, Amsterdam.

Ima, A. \& Wenti, R., (2011).” Identifying business ethics implementation in Islamic perspective on Micro business of foods and beverages in Bandung "Research Report, Bandung: LPPM Unisba

Ima., A. (2014). Factors that influence Islamic working ethics and motivation and its implications on the satisfaction of Islamic work performance: Case study on Embroidery Business unit in Tasikmalaya. Dissertation: Jakarta; Trisakti University.

Jamal, A. (2003), "Marketing in a multicultural world: the interplay of marketing, ethnicity and consumption". European Journal of Marketing, 37(11),1599-620.

Kassem, R., \& Higson, A. (2012). The New Fraud Triangle Model. Journal of Emerging Trends in Economics and Management Sciences, 3(3), 191-195.

Klockars, C.B., Ivkovich, S.K., Harver, W.E., \& Haberfeld, M.R. (2000). The Measurement of Police Integrity, National Institute of Justice, United States Department of Justice. Washington, DC.

KPMG (2012). Australian and New Zealand Fraud Survey. Published by KPMG. From https:// www.kpmg.com/NZ/en/IssuesAndInsights/ ArticlesPublications/Documents/FraudBribery-and-Corruption-Survey-2012.pdf

KPMG (2013). KPMG Malaysia Fraud, Bribery and Corruption Survey 2013, Malaysia.KPMG publisher. From https://www.kpmg.com/MY/ en/IssuesAndInsights/ArticlesPublications/ Documents/2013/fraud-survey-report.pdf
Kranacher, M. J., Riley, R.A. Jr \& Wells, J.T. (2011). Forensic Accounting and Fraud Examination. John Wiley \& Sons, New York, NY.

Kula, V., Yilmaz, C., Kaynar, B., \& Kaymaz, A. R. (2011). Managerial Assessment of Employee Fraud Risk Factors Relating to Misstatements Arising From Misappropriation of Assets: A Survey of ISE Companies. International Journal of Business and Social Science, 2(23), 171-180.

Levi, M. (2008). Organized Frauds and Organizing Frauds: Unpacking The Research on Networks And Group. Criminology and Criminal Justice, 8(4), 389-419.

Liew, S. W. S., Puah, C.H., Entebang, H. (2011). White-collar crime: A Statistical Study on its Common Causes. International Journal of Business, Management and Social Sciences, 2(4),44-49.

Lister, L. (2007). A practical approach to fraud risk. Internal Auditor, 64(6), 61-65.

M. Sham, M.,F., \& Yusof.S., (2015). Religiosity of Muslim Adolescents from Single Parent Families Living in Government-Subsidised Settlement. Global Journal Al-Thaqafah, 5(2), $1-12$.

Majid, A. R., Mohamed, N., Haron, R., Omar, N.B., \& Jomitin, B. (2014). Misappropriation of Assets in Local Authorities: A Challenge to Good Governance, Procedia Social and Behavioral Sciences, 164(2014),345-350 ..

Mui, G., Milley J., (2015). A tale of two triangles: comparing the Fraud Triangle with criminology's Crime Triangle. Accounting Research Journal, 28(1), 45-58. 
Mui, T.L., (2014). The Announcement Effect Of White Collar Crime On Stock Price By Public Listed Companies In Malaysia, Master thesis, Corporate and Business Administration, UNIMAS, Sarawak, Malaysia.

Musa, N. (2014). “ Penerapan Konsep Mas'uliyyah dan Amanah dalam Pentadbiran Awam ke Arah Bersih Rasuah-Kajian di Majlis Perbandaran Kota Bharu Bandaraya Islam https://www.academia.edu/10049119/ Penerapan_Konsep_Masuliyyah_dan Amanah_dalam_Pentadbiran_Awam_ke_ arah_Bersih_Rasuah_-_Kajian_di_Majlis Perbandaran_Kota_Bharu-Bandaraya_Islam MPKB-BRI_.

Nia, E.H. (2016). Assessing Fraud Risk Factors of Asset Misappropriation In Iranian Banks: Fraud Diamond Theory. Master, Master of Science, UiTM Shah Alam.

Nunally, J.C. (1978). Psychometric theory (1st edition). New York: Mc-Graw Hill. Inc

Pallant, J. (2007). SPSS survival manual (3rd edition). Open University Press, Buckingham, Philadelphia.Retrieved fromhttps://www.mheducation.co.uk/openup/ chapters/0335208908.pdf

Paul, C., Colin F., Moroney R., (2008). "Internal Audit, Alternative Internal Audit Structures and The Level of Misappropriation of Assets Fraud". Accounting \& Finance, 48(4), 543-559..

Pupung, P., \& Ima, A. (2015). Fraud Prevention: Relevance to Religiosity and Spirituality in The Workplace. Procedia Social and Behavioral Sciences, 211(2015), 827-835.

Rezae, Z., \& Davani, H. (2013). Does Financial Reporting Fraud Recognize Borders? Evidence from Bank Fraud in Iran. Journal of Forensic \& Investigative Accounting, 5(2), 1-15.
Rezaee, Z. (2005). Causes, Consequences, and Deterrence of financial statement fraud. Critical Perspectives on Accounting, 16(3), 277-298.

Said, J.,Bakri, M.H.H., \& Abdul Karim, Z., (2015). Case Study on Integrity among Royal Malaysian Police (RMP): An Ethical Perspective. Procedia Economics and Finance, 28(2015), 121-125.

Sharma, P. (2014). Corruption is a First World Problem, Too, 17 November, World Economic Forum. From https://www.weforum.org/ agenda/2014/11/corruption-is-a-first-worldproblem-too/

Shukor, S. A., \& Jamal, A. (2013). Developing Scales for Measuring Religiosity in the Context of Consumer Research. Middle-East Journal of Scientific Research 13(2013), 69-74.

Siguaw, J. A., \& Simpson, P. M., (1997). Effects of Religiousness on Sunday Shopping and Outshopping Behaviors: A Study of Shopper Attitudes and Behaviors in the American South. International Review of Retail, Distribution and Consumer Research, 7(1), 23-40.

Society for Human Resource Management SHRM (2008). Religion and Corporate Culture: Accommodating Religious Diversity in the Workplace report. Retrieved from https://www. shrm.org/hr-today/trends-and-forecasting/ research-and-surveys/Documents/080625ReligionSR_updtFINAL.pdf

Transparency International (2011). Corruption perceptions Index 2011. Transparency International publisher, Germany. From file://C:/Users/User_2/Downloads/TI_ CPI_2011_report_view.pdf.pdf

Tugas, F.C. (2012). Exploring A New Element of fraud: A study on Selected Financial Accounting Fraud Cases in the world. American International Journal of Contemporary Research, 2(6), 1-10. 
Voon, S.L., Puah, C.H., \& Entebang, H. (2008). Widianingsih, L. P. (2013). Students Cheating Corporate crime announcement effects on stock Behaviors: The Influence of Fraud Triangle. performance: An empirical study in Malaysia. Review Integrity Business Economics Research, Journal of Economic Cooperation, 29(2), 15-28. 2(2), 252-260.

Weaver, G. \& Agle, B. (2002). Religiosity and Ethical Behavior in organizations: A symbolic Interactionist Perspective. Academy of Management Review, 27(1), 77-97.

Weisburd, D., Greenspan, R., Hamilton, E.E., Williams, H. \& Bryant, K.A. (2000). Police Attitudes Toward Abuse of Authority: Findings From a National Study, National Institute of Justice, Washington, DC U.S. Department of Justice, National Institute of Justice.

Wells, J. T. (2001). Why Employees Commit Fraud: It's either greed or need. Journal of Accountancy, 191(2), 129-92.
Wolfe, D. T., \& Hermanson, D. R. (2004). The Fraud Diamond: Considering the Four Elements of Fraud. The CPA Journal, 74(12), 38-42.

Zakaria, T.A, (2013). Corruption In Legal System (Malaysian Perspective On Corruption In Legal System). 5th Meeting "Developing Judicial Capabilities To Enhance Public And International Confidence In Legal System, 1st November 2013, Singapore. From: http://www. apjrf.com/'Malaysian $\% 20$ Perspective $\% 20$ on $\% 20$ Corruption $\% 20 \mathrm{in} \% 20$ Legal $\% 20$ System'.pdf 
